\title{
BIOTRANSFORMATION OF CITRONELLOL IN ROSE-OXIDE USING CASSAVA WASTEWATER AS A MEDIUM ${ }^{1}$
}

\author{
Mário Roberto MARÓSTICA JR.,2, Gláucia Maria PASTORE²
}

\section{SUMMARY}

The use of liquid cassava waste (manipueira) as the medium for the biotransformation of citronellol using a Penicillium sp strain was studied. The strain was able to grow in the waste and production of cellular mass reaching $25 \mathrm{~g} / \mathrm{L}$ over three days of contact of the spores with the medium. Submerged cultures of Penicillium sp grown in manipueira were able to convert the substrate into cis- and trans-rose oxides when the cells were transferred into a mineral medium for the biotransformation experiments. The production of rose oxide increased by more than 2.4 times using this 2 media process as compared to processes using only a manipueira medium (cassava medium). Auto-oxidation products were not detected in the control experiments.

Keywords: biotransformation, manipueira, citronellol, Penicillium sp.

\section{RESUMO}

BIOTRANSFORMAÇÃO DE CITRONELOL EM ÓXIDO DE ROSA UTILIZANDO MANIPUEIRA COMO MEIO DE CULTURA. A utilização de resíduo líquido do processamento de mandioca (manipueira) como meio de cultura para a biotransformação de citronelol por uma linhagem de Penicillum sp foi estudada. A linhagem foi capaz de se desenvolver na presença do resíduo atingindo produção de massa celular da ordem de $25 \mathrm{~g} / \mathrm{L}$ durante três dias de contato dos esporos com o meio. Culturas submersas de Penicillium sp desenvolvidas em manipueira foram capazes de converter o substrato a cis- e trans-óxidos de rosa quando as células foram transferidas a um meio mineral. Pôde-se observar que a produção de óxido de rosa sofreu um aumento maior que 2,4 vezes através desse processo em comparação à utilização apenas do meio de manipueira (meio de mandioca). Produtos de auto-oxidação não foram identificados nos experimentos controle.

Palavras-chave: biotransformação, manipueira, citronelol, Penicillium sp.

\section{1 - INTRODUCTION}

Citronellol is a perfumed, flavoring compound of great interest to industrial companies as it can be used to synthesize other aroma compounds, such as rose oxide [14, 5]. Citronellol can be used to produce floral notes [22]. The biotransformation of citronellol can produce a large amount of metabolites $[14,20,6,10]$ and one of the most interesting compounds is rose oxide.

Rose oxide is found in small amounts in some plants such as the Bulgarian rose, Geranium, Damask rose [3], Laggera Spp [16], Eucalyptus citriodora [27] and Dracocephalumheterophyllum Benth, a cold desert plant containing $1.6 \%$ of cis-rose oxide, $0.5 \%$ of trans-rose oxide and $7.4 \%$ of citronellol in its essential oil [15].

L-cis-rose oxide is a strong fruity flavor compound and has a small odor threshold: $0.5 \mathrm{ppb}$, while d-cis-rose oxide possesses a herbal odor and odor threshold of $50 \mathrm{ppb}$. L-cisrose oxide can be chemically synthesized from $S$-citronellol [5]. The organic synthesis of (+)-cis-rose oxide from $R-(+)$ methylcyclohexanone as the initial material was described by a Canadian research group [12].

\footnotetext{
${ }^{1}$ Recebido para publicação em 8/12/2005. Aceito para publicação em 6/7/2006 (001648)

${ }^{2}$ Laboratory of Bioflavors, Department of Food Science (FEA),

(UNICAMP), P. O. Box 612, Barão Geraldo, CEP 13083-970,

Campinas (SP), Brazil,

E-mail:mario@fea.unicamp.br

* A quem a correspondência deve ser enviada
}

Biotransformation can be considered as an advantageous alternative for chemical synthesis as the enzymes are capable of enantioselective hydrolysis producing enantiospecific compounds labeled as 'natural' according to the American and European regulations [23].

Due to this some authors have proposed the biotransformation of citronellol. In 1987, a research group described the biotransformation of citronellol using a strain of the noble grape rot fungus Botrytis cinerea [6]. The main metabolites were 2.6-dimethyl-1.8-octadienol and (E)-2.6-Dimethyl-2octen-1.8-diol as a result of $\omega$-hydroxylation. The authors reported the use of grape must, a synthetic mineral medium and a combination of both (in proportions of 1-5:700 grape must: mineral medium) as a media for the biotransformation of citronellol in their experiments.

The use of enzymes for biotransformation is also a feasible approach, as described by KAMINSKA et al [14]. They described the biotransformation of citronellol as a horseradish peroxidase-hydrogen peroxide system in the presence of ascorbic acid as the proton donor.

ONKEN \& BERGER proposed a greater scale process for the biotransformation of citronellol [20]. A strain of the basidiomycete Cystoderma carcharias achieved $0.15 \mathrm{~g} \mathrm{~L}^{-1} \mathrm{~d}^{-1}$ of biotransformation products in a $2 \mathrm{~L}$ aerated-membrane bioreactor. The increased gas-exchange surface provided higher oxygen saturation, growth and transformation rates. The main product was 3.7-dimethyl-1, 6.7-octanetriol. 3.7dimethyl-6.7-epoxy-1-octanol was identified as an important intermediary product of the biotransformation and the allylic 
diols 2.6-dimethyl-2-octene-1.8diol, 3.7-dimethyl-5-octene1.7-diol and 3.7-dimethyl-7-octene-1.6-diol were found to be minor products as well as cis/trans-rose oxide (first report of the microbial formation of rose oxide). The authors suggested that a cytochrome P-450 monooxygenase was involved in the first oxy-functional step and subsequent steps were catalyzed by hydrolase and transferase enzymes.

More recently, DEMYTTENAERE, VANOVERSCHELDE \& DE KIMPE proposed the use of SPME (Solid Phase Micro Extraction) to screen strains capable of biotransforming citronellol. The authors found that rose oxide was obtained by a combination of biotransformation and acid-catalyzed heat conversion [10].

The use of agro-industrial residues in bioprocesses is a feasible alternative as it provides alternative substrates, as well as helping to solve pollution problems. Liquid cassava waste originates from pressing cassava roots [8]. It is considered to be a "harmful" pollutant waste due to its high organic content and presence of cyanide, resulting from the cyanidic glycosides (linamarin and lataustralin) of the cassava roots. These compounds leach into the residual liquid during the process and are hydrolyzed to cyanide by enzymatic action [19]. On the other hand, the liquid cassava waste can be considered to be rich in nutrients that can be used in other applications.

This study investigated the use of cassava wastewater in the biotransformation of the substrate citronellol into rose oxides and the effects of citronellol as the sole $\mathrm{C}$ - and energy-sources for the biotransformation experiments.

\section{2 - MATERIAL AND METHODS}

\section{1 - Chemicals and reagents}

(+/-)-Citronellol was purchased from the Aldrich Chemical Company and the cis- and trans-rose oxides were from Fluka. All other chemicals and solvents were of the best available commercial grade.

\section{2 - Microorganisms and cultivation}

The Penicillium sp strain was isolated from a very ripe mango from the North East of Brazil. The cultures were cultivated and conserved by periodic replications on YeastMalt agar (0.5\% YM: bacteriological peptone, $1.0 \%$ glucose, $0.3 \%$ malt extract, $0.3 \%$ yeast extract and $2.0 \%$ agar, $\mathrm{pH} 6.0$ ) at $30{ }^{\circ} \mathrm{C}$.

\section{3 - Cassava medium (CM) preparation}

Cassava effluent obtained from the manufacturing of cassava flour (the residue was donated by a Cassava Flour Industry located in Sao Paulo, Brazil) was collected and stored at $-18{ }^{\circ} \mathrm{C}$ until needed. The medium was prepared by heating the waste to boiling point to remove solids. After cooling, the substrate was centrifuged at $10,000 \times \mathrm{g}$ for $20 \mathrm{~min}$. The supernatant was sterilized at $121^{\circ} \mathrm{C}$ for
20 min. The result of the $\mathrm{pH}$ of the medium was 6.0 and was not adjusted.

\section{4 - Determination of the cassava medium composition}

\subsection{1 - Determination of the total carbohydrates in the cassava medium}

The total number of carbohydrates was determined by a colorimetric method based on the Phenol reaction with glucose, as described by DANIELS, HANSON \& PHYLLIPS [9].

\subsection{2 - Determination of the reducing sugar contents in the cassava medium}

The total number of reducing sugars (TRS) was quantified according to SOMOGY [25] and NELSON [18] using glucose as the standard.

\subsection{3 - Determination of the nitrogen content of the cassava medium}

The protein content was calculated from the nitrogen content as determined by the Kjeldahl procedure using 6.25 as the conversion factor [2].

\subsection{4 - Determination of the mineral content of the cassava medium}

Cassava medium ( $1 \mathrm{~mL}$ ) was incinerated for $3 \mathrm{~h}$ at $500{ }^{\circ} \mathrm{C}$. Afterwards, $5.0 \mathrm{~mL}$ of $6 \mathrm{M} \mathrm{HCl}$ was added and evaporated to dryness. The residue was transferred to a $50 \mathrm{~mL}$ volumetric flask, water was added to the volume and it was shaken and filtered. The minerals were determined using an Atomic Emission Spectrophotometer (Jobin Yvon, model JY 50P). The spectral lines for each element were (in nm): P, 178; K, 766, Ca, 317; Mg, 279; Mn, 257; Fe, 259; Cu, 324; Zn, 213; and S, 180.

\section{5 - Mineral medium (MM)}

The mineral medium composition was $0.5 \mathrm{~g}$ of $\mathrm{Mg}$ $\mathrm{SO}_{4} ; 3.0 \mathrm{~g}$ of $\mathrm{NaNO}_{3} ; 1.0 \mathrm{~g}$ of $\mathrm{K}_{2} \mathrm{HPO}_{4} ; 0.5 \mathrm{~g} \mathrm{KCl}$ and $0.01 \mathrm{~g}$ of $\mathrm{Fe}_{2} \mathrm{SO}_{4}$ in $1.0 \mathrm{~L}$ of distilled water [6]. The medium was sterilized in an autoclave at $121^{\circ} \mathrm{C}$ for $20 \mathrm{~min}$. The $\mathrm{pH}$ was 7.0 and was not adjusted.

\section{6 - Biotransformation experiments}

The strain was cultivated in $250 \mathrm{~mL}$ conical flasks containing $50 \mathrm{~mL}$ of liquid medium. The biotransformation experiments (all in duplicate) were done with cassava medium (CM), mineral medium (MM) and with a combination of cassava medium (where the cells were grown) and mineral medium (where the biotransformaitons were conducted by citronellol addition). In the first experiment, using cassava 
medium, $50 \mathrm{~mL}$ of culture medium were inoculated with $2.5 \mathrm{~mL}$ of a spore suspension (1-7 $\times 10^{7}$ spore $\left.\mathrm{mL}^{-1}\right)$ in water. Cultivation was carried out in a rotary shaker at $160 \mathrm{rpm}$ and $30{ }^{\circ} \mathrm{C}$. After 3 days, the biotransformation process was started by adding $50 \mu \mathrm{L}$ citronellol (under sterile conditions). In the second experiment, the mineral medium was used, but the procedure was the same as in the first experiment. In the third experiment, culture growth was started in the cassava medium and continued for 3 days. The culture was then filtered through Whatman filter paper (sterilized in an autoclave at $121{ }^{\circ} \mathrm{C}$ for $20 \mathrm{~min}$ ) under sterile conditions. The cell mass was rinsed 3 times with distilled, sterilized $\left(121{ }^{\circ} \mathrm{C}\right.$ for $20 \mathrm{~min}$ ) water and transferred into another flask containing $50 \mathrm{~mL}$ of mineral medium. Biotransformation was initiated by adding $50 \mu \mathrm{L}$ citronellol (under sterile conditions). In all the experiments, biotransformation started 3 days after inoculation by adding $50 \mu \mathrm{L}$ of citronellol directly into the culture flasks. Two subsequent additions of $50 \mu \mathrm{L}$ were made every $24 \mathrm{~h}$. The experiments were conducted for another 3 days after the last addition. In the same way, chemical blanks with the pH adjusted to 3.0, 4.0 and 5.0 (the $\mathrm{pH}$ adjustments were made using $\mathrm{HCl}$ prior to autoclaving) were performed for each biotransformation experiments (but without mycelium) to ensure the absence of chemical transformation reactions. At 24, 48, 72, 96 and 120 hs after adding citronellol, $5 \mathrm{~mL}$ samples were taken and extracted with $5 \mathrm{~mL} \mathrm{Et}_{2} \mathrm{O}$. The samples were analyzed by GC/FID immediately (decane was the internal standard).

\section{7 - Induction experiments}

The same strain was cultivated in $50 \mathrm{~mL}$ conical flasks with $20 \mathrm{~mL}$ of cassava medium and inoculated with $1 \mathrm{~mL}$ of spore suspension (1-7 $\left.\times 10^{7}\right)$ in water and cultivation was done in the same way as described above. After 2 days, $10 \mu \mathrm{L}$ of citronellol was added to the flask. Two more additions were made after 2 and 3 days. After 5 days, the culture was transferred to an agar plate (YM medium). After 4 days of growth on the agar plate, this culture was submitted to the biotransformation of citronellol in the same way as described above (using the composition labeled as $\mathrm{CM}+\mathrm{MM}$ ).

\section{8 - Analysis of the samples by GC}

GC-analyses for the biotransformation products were performed using a Chrompack CP 9001 equipped with a split/ splitless-injector, a FID-detector, a WCOT fused silica column and stationary phase of CP-Sil CB (60 m length $\times 0.25 \mathrm{~mm}$ i.d.; coating thickness $0.25 \mathrm{~mm}$ ). The working conditions were: injector $220{ }^{\circ} \mathrm{C}$, detector $250{ }^{\circ} \mathrm{C}$ (make-up gas $\mathrm{He}$ $1 \mathrm{~mL} / \mathrm{min}$ ). The oven temperature was programmed from $40^{\circ}$ to $210^{\circ}$ at $5^{\circ} \mathrm{C} / \mathrm{min}$ with an initial holding time of $1 \mathrm{~min}$ and a final holding time of $5 \mathrm{~min}$, split 1/10.

Chiral GC-analyses were performed using the same GC equipped with a Beta Dex 120 chiral column (60 m x $0.25 \mathrm{~mm}$ i.d. coating thickness $0.25 \mu \mathrm{m}$ ). The working conditions were: injector $220{ }^{\circ} \mathrm{C}$, detector $250{ }^{\circ} \mathrm{C}$ (make-up gas He $1 \mathrm{~mL} / \mathrm{min}$ ). The oven temperature was programmed from
$110{ }^{\circ} \mathrm{C}$ to $170{ }^{\circ} \mathrm{C}$ at $1{ }^{\circ} \mathrm{C} / \mathrm{min}$ with an initial holding time of $10 \mathrm{~min}$ and a final holding time of $5 \mathrm{~min}$.

GC-MS-analyses to determine the biotransformation products were performed with a Shimadzu GC/MS Class 5000 with helium as the carrier gas and fused silica capillary columns of SUPELCO SIMPLICITY $1^{\mathrm{TM}}$ (30 m x $0.25 \mathrm{~mm} \times$ $0.25 \mu \mathrm{m})$. The working conditions were: injector at $260{ }^{\circ} \mathrm{C}$, the oven temperature was programmed from $50{ }^{\circ} \mathrm{C}(1 \mathrm{~min}$ of initial holding time) to $150{ }^{\circ} \mathrm{C}$ ( 1 min of holding time) at $4{ }^{\circ} \mathrm{C} / \mathrm{min}$, and from $150{ }^{\circ} \mathrm{C}$ to $280{ }^{\circ} \mathrm{C}(2 \mathrm{~min})$ at $30{ }^{\circ} \mathrm{C} / \mathrm{min}$, with a final holding time of $2 \mathrm{~min}$, scan range of $\mathrm{m} / \mathrm{z} 40-500$, carrier gas (He) $1.7 \mathrm{~mL} / \mathrm{min}$; split 1/50; ionization EI $70 \mathrm{eV}$.

\section{3 - RESULTS AND DISCUSSION}

\section{1 - Manipueira as a bioconversion medium}

Manipueira is a residue which comes from pressing cassava roots in the process of cassava flour manufacturing. It is generated at the rate of $250 \mathrm{~L}$ per ton of cassava [8]. The major nutrients present in cassava waste are sugars (sucrose, glucose, fructose and maltose), nitrogen and mineral salts. Its richness in C-source turns manipueira into a suitable medium to cultivate microorganisms, contributing to make this a feasible industrial biotechnological process as the raw material represents $30 \%$ of the total costs [7].

Cassava medium (CM) presents high contents of $\mathrm{C}$, $\mathrm{N}$-sources and minerals, which are responsible for the great mycelial development. On the other hand, the medium also presents high contents of substances that could limit the microrganism growth or inhibit the capacity of biotransformation, such as cyanide. Cassava water was tested as a medium for the bioconversion of citronellol by a Brazilian Penicillium sp strain. Table 1 presents the composition of the cassava medium used in this study. It should be noticed that the cassava medium was shown to be a suitable medium for cell mass production using the strain tested. This was proved from the rate of cell mass development. After 3 days of contact with the cassava medium, the Penicillium strain was able to reach $25 \mathrm{~g} / \mathrm{L}$ in the cassava medium. Taking this into account, this implies a cheaper and advantageous biotechnological process, as in this case, a valuable flavor compound can be produced.

\section{2 - Chemical stability of citronellol in submerged liquid broths}

Blank experiments with citronellol in the same medium were done to check the chemical stability of the terpenoid in submerged liquid broths. Conical flasks (250 mL) were filled with $50 \mathrm{~mL}$ of mineral and cassava water media. The $\mathrm{pH}$ of each was adjusted to 3.0, 4.0 and 5.0 and shaken. After 7 days of shaking, no chemical oxidation or auto-oxidation were detectable in the culture broths.

This is compatible with DEMYTTENAERE, VANOVERSCHELDE \& DE KIMPE [10], who reported the chemical stability of citronellol in submerged liquid broths with an 
TABLE 1 - Physicochemical composition of manipueira (cassava wastewater).

\begin{tabular}{lcc}
\hline \multicolumn{1}{c}{ Components } & \multicolumn{2}{c}{ Concentration } \\
\hline Total carbohydrates & 39.50 & $\mathrm{~g} / \mathrm{L}$ \\
Non-reducing sugars & 20.12 & $\mathrm{~g} / \mathrm{L}$ \\
Reducing sugars & 19.38 & $\mathrm{~g} / \mathrm{L}$ \\
Total Nitrogen & 1.72 & $\mathrm{~g} / \mathrm{L}$ \\
Phosphorous & 368.8 & $\mathrm{mg} / \mathrm{L}$ \\
Potassium & 3641.0 & $\mathrm{mg} / \mathrm{L}$ \\
Calcium & 236.0 & $\mathrm{mg} / \mathrm{L}$ \\
Magnesium & 438.1 & $\mathrm{mg} / \mathrm{L}$ \\
Sulfur & 61.35 & $\mathrm{mg} / \mathrm{L}$ \\
Iron & 2.72 & $\mathrm{mg} / \mathrm{L}$ \\
Zinc & 3.01 & $\mathrm{mg} / \mathrm{L}$ \\
Manganese & 3.46 & $\mathrm{mg} / \mathrm{L}$ \\
Copper & 1.11 & $\mathrm{mg} / \mathrm{L}$ \\
$\mathrm{pH}$ & 6.0 & - \\
\hline
\end{tabular}

YMPG medium (pH adjusted to 5.0 and 3.5) in a rotary shaker for 1 week. However, the same authors proposed an acid-catalyzed chemical reaction for citronellol in YMPG solid media. They found that citronellol was converted to cis/trans-rose oxide, Nerol oxide, linallol and $\alpha$-terpineol in solid media with $\mathrm{pH}=3.5$ after 3 days of contact. The commercial production of rose oxides started with the photooxygenation of citronellol [10].

\section{3 - Comparison of the strains and media}

Lipophilic compounds, such as terpenoids, are preferentially dissolved in the lipohilic membrane systems of fungal cells [1]. The terpenoids, and other lyophilic compounds induce changes in the membrane properties causing toxic effects, which explains the low yields related to the biotransformation of terpenoids [20].

The biotransformation experiments were done in media with three different compositions, labeled as CM, MM and $\mathrm{CM}+\mathrm{MM}$ (see material and methods).

The mineral medium had no $\mathrm{C}$ or $\mathrm{N}$ sources and consequently no cell mass development occurred. Furthermore, when the culture was submitted to the mineral medium (MM), no transformation compounds could be detected implying that there was no spore activity concerning the biotransformation of citronellol by the strains used in the present investigation. The final $\mathrm{pH}$ of the mineral medium after the biotransformation was 6.0.

Inhibition of fungal growth by adding citronellol was evident. When terpene was added, the cell mass maintained a constant value (about $25 \mathrm{~g} / \mathrm{L}$ ), while in the control cultures without citronellol, the strain continued to grow after 3 days reaching values of $40 \mathrm{~g} / \mathrm{L}$.

The biotransformation of citronellol in the cassava medium produced very low concentrations of the expected compounds, reaching approximately $10 \mathrm{mg} / \mathrm{L}$ of trans-rose oxide in four days of biotransformation. The final $\mathrm{pH}$ of the cassava water medium was around 3.5.

For the strain tested, rose oxide concentrations were much higher when the mycelium developed in cassava medium was transferred to mineral medium and the bioconversion occurred with citronellol as the sole C- and energy sources (final pH around 5.0). The concentrations of the products recovered are shown in Table 2.

It was found that sporulated surface cultures of Penicillium sp. were able to convert citronellol into cis- and trans-rose oxides. Other biotransformation products were 3.7-dimethyl-1.6-octadien-3-ol and 6-methyl-5-hepten-2-ol. The presence of 1-octen was also detected, but this is not a usual biotransformation product of citronellol. 1-octen is not described in the literature as a result of biotransforming citronellol. In this experiment, 1-octen can be regarded as an artifact. Generally, biotransformations of terpenoids lead to oxyfunctionalized products. No chemical oxidation or auto-oxidation products were detected in the liquid control broths. The experiments were conducted at $30{ }^{\circ} \mathrm{C}$ and $160 \mathrm{rpm}$. When the medium was cassava, the production of rose oxide reached approximately $40 \mathrm{mg} / \mathrm{L}$ whilst the other minor products only reached trace amounts. However, when the mycelium was developed in the cassava medium and than transferred into the mineral medium (citronellol as the sole C-source) the concentrations of rose oxide increased, reaching more than 70 and $30 \mathrm{mg} / \mathrm{L}$ for the cis- and transisomers respectively. The residual citronellol was found in high concentrations, meaning the process was still not optimized, considering the substrate concentration. The minor compounds did not show increased concentrations. Figure 1 shows the main compounds resulting from the biotransformation of citronellol by the Penicillium sp strain.

The biotechnological production of rose oxide shown here is compatible with that of previous investigations. This bioconversion mediated by a Penicillium roqueforti strain has already been described [10]. In this case, cytochrome P450 enzymes were probably involved. This enzyme system affects the fungi by turning the terpenoids (which are lypophilic compounds and adhere to the membrane) into more soluble compounds, causing a detoxification process [20]. Figure 2 illustrates the conversion of citronellol into rose oxide.

TABLE 2 - Products recovered from cassava liquid culture broths (concentrations in mg/L) after 5 days of biotransformation.

\begin{tabular}{|c|c|c|c|c|c|c|}
\hline Medium & $\begin{array}{l}\text { cis-rose oxide } \\
\text { (I) }\end{array}$ & $\begin{array}{l}\text { trans-rose oxide } \\
\text { (II) }\end{array}$ & $\begin{array}{l}\text { 1-octen } \\
\text { (III) }\end{array}$ & $\begin{array}{c}\text { 3,7-dimethyl-1,6-octadien-3-ol } \\
\text { (IV) }\end{array}$ & $\begin{array}{l}\text { citronellol } \\
\text { (V) }\end{array}$ & $\begin{array}{c}\text { 6-methyl-5-hepten-2-ol } \\
\text { (VI) }\end{array}$ \\
\hline $\mathrm{CM}$ & 30.6 & 11.9 & t.a. & 5.3 & 275.5 & t.a. \\
\hline $\mathrm{CM}+\mathrm{MM}$ & 73.4 & 31.5 & n.d. & 4.9 & 292.5 & t.a. \\
\hline
\end{tabular}




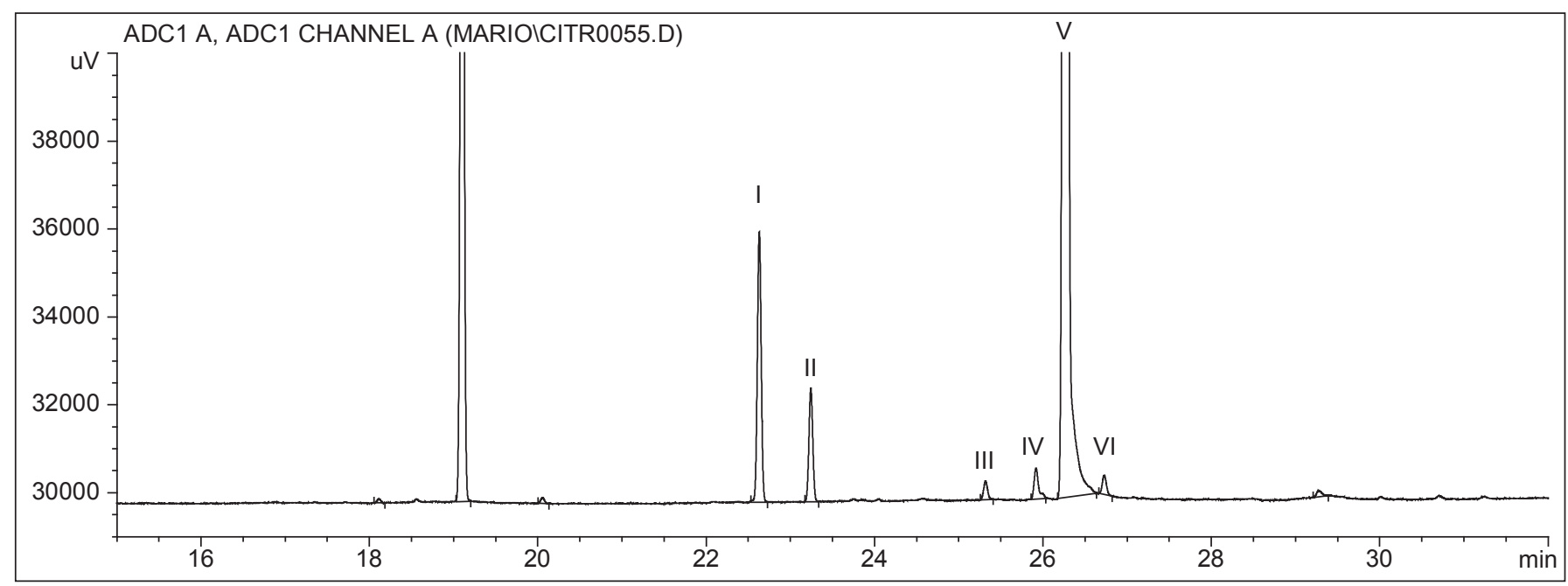

FIGURE 1 - Compounds recovered after the biotransformation of citronellol in CM+MM by Penicillium sp. Train [(I) cis-Rose oxide, (II) trans-Rose oxide, (III) 1-octen, (IV) 3,7-Dimethyl-1,6-octadien-3-ol, (V) citronel, (VI) 6-Methyl-5-hepten-2-ol].

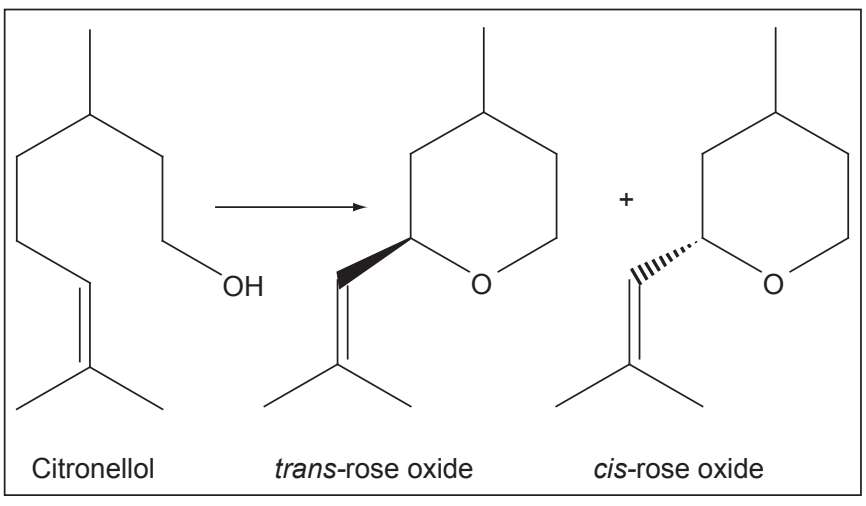

FIGURE 2 - Conversion of citronellol in cis- and trans-rose oxides by Penicillium sp in cassava medium.

\section{4 - Induction experiments}

A parameter showing the toxicity of solvents for microrganisms is the $\log \mathrm{P}_{\mathrm{OW}}$ (logarithm of the partition coefficient of the substance in an n-octanol/water system). The strongest toxicities were observed for solvents with a $\log \mathrm{P}_{\text {ow }}$ between 1 and 5 [20]. Compounds like citronellol ( $\log \mathrm{P}_{\text {ow }}=3.5$ [13]) are toxic for microrganisms.

In the present study, the resistance of the Penicillium sp strain in the presence of the monoterpene citronellol was observed. The cells were put into contact with citronellol for 8 days to first deplete the $\mathrm{C}$ and $\mathrm{N}$ sources, subsequently forcing the strain to metabolize the terpene. The culture was transferred to an agar plate after 5 days. After 4 days on the plate, the appearance of the culture was significantly different from that of the wild one, although it still looked like a Penicillium strain. The contamination hypothesis cannot be considered as all the procedures were done under sterile conditions and the 'induced strain' still looked like a Penicillium strain. This kind of morphological modification has already been reported. A Hormonema sp. yeast strain biotransformed the inexpensive limonene and the authors reported a non-reproducible conversion to trans-iso-piperitenol. This non-reproducible process was explained on the basis of morphological modifications of the strains during the course of biotransformation [28].

In the present study, morphological modifications could not be detected during the course of biotransformation, however the appearances of the 'wild' and 'induced' strains were different (as shown in Figure 3). The differences in appearance could be explained by the interactions that terpenes (due to lipophilic characteristics) can promote in the membrane [21]. Some investigations report that terpenes can interact with biological membranes. These interactions lead to changes in structure and function of the membranes, which in turn, may impair growth and activity of the cells. The toxicity of cyclic hydrocarbons has been well noted, but knowledge about their mode of interaction with cells and the cause of toxicity is scarce [24]. In this experiment, the differences of color between the wild and induced strains are evident (Figure 3). The differences in color can be caused by the action of citronellol in the production extracellular materials (such as the pigments) by the fungi. The biosynthesis of melanin and melanin-like compounds (present in Penicillium sp. strains [29]) could be modified by the action of citronellol or its biotransfomation products in the membrane. This was also observed for Hormonena sp strains when exposed to limonene [28]. The authors report modifications in slime and melanin production by the strains in contact with limonene.

The biotransformation carried out with the 'induced strain' was done in the same way as for the 'wild strain'. Unfortunately, the production of rose oxides by the 'induced strain' was not significantly higher as compared to the 'wild one' and an increase of less than $10 \%$ was observed in the production of rose-oxides. 


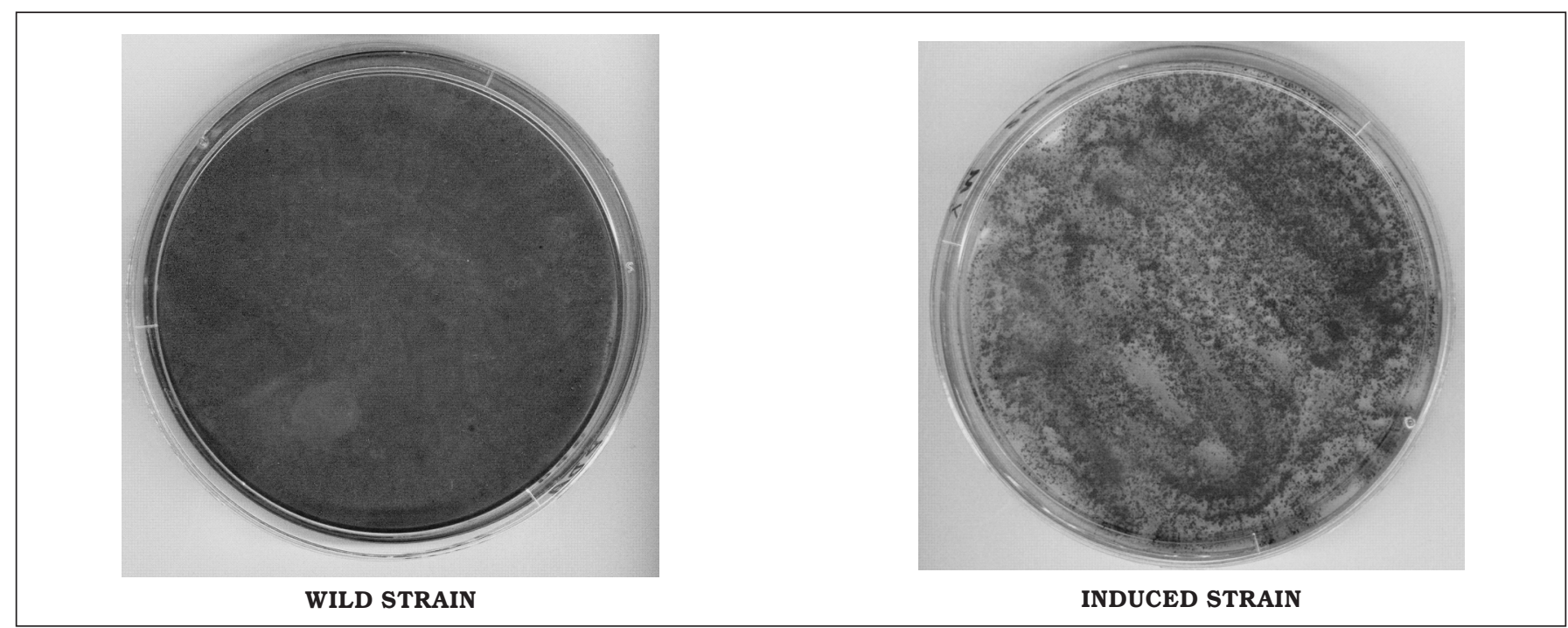

FIGURE 3 - Agar plates of wild and citronellol-induced strains of Pecicillium sp. The wild strain was obtained after contact with citronellol in liquid culture medium.

\section{4 - CONCLUSIONS}

In this study, rapid growth of the fungi tested was observed in the presence of cassava medium. The biotransformation of citronellol resulted in the production of cis- and trans-rose oxides as the main products. The production of rose oxides was much higher when citronellol oil was the sole $\mathrm{C}$-source as compared to experiments in a transformation medium where other $\mathrm{C}$ and $\mathrm{N}$-sources were present (bioconversion in the presence of cassava medium). An attempt at induction showed a very slight increase in the concentration of the targeted products. There was a clear modification in the appearance of the 'induced strain', probably caused by the action of citronellol or its biotransformation products in the membrane of the fungi.

\section{5 - REFERENCES}

[1] ABRAHAM B.; ONKEN, J. G.; BERGER, R. G. Strategies toward an efficient biotechnology of aromas. In: Proceedings of the $5^{\text {th }}$ Wartburg Aroma Symposium. 1997, Eisenach, Eigenverlag Universität Potsdam, p. 357-373.

[2] AOAC. Official Method of Analysis - The Association of Official Analytical Chemists, 16th ed. Virginia, 1995.

[3] BABU, K. G. D.; SINGH, B.; JOSHI, V. P.; SINGH, V. Essential oil composition of Damask rose (Rosa damascena Mill.) distilled under different pressures and temperatures. Flav. Fragr. J., v. 17, n. 2, p. 136-140, 2002.

[4] BERGER, R. G. (Ed.). Aroma biotechnology. BerlinHeidelberg: Springer-Verlag, 1995.

[5] BOERSMA, Y. L.; SCHELTINGA, P. C.; DRÖGE, M. J.; BOS, R.; QUAX, W. J. A validated gas chromatographic method for the evaluation of enzymatic enantioselectivity in kinetic resolution applications. J. Sep. Sci, v. 28, n. 6, p. 501-505, 2005 .
[6] BRUNERIE, P.; BENDA, I.; BOCK, G.; SCHREIER, P. Bioconversion of citronellol by Botrytis cinerea. Appl. Microbiol. Biotechnol., v. 27, n. 1, p. 6-10, 1987.

[7] CAMEOTRA, S. S.; MAKKAR, R. S. Synthesis of biosurfactants in extreme conditions. Appl. Microbiol. Biotechnol., v. 50, p. 520-529, 1998.

[8] DAMASCEnO, S.; CEREDA, M. P.; PASTORE, G. M. Desenvolvimento de Geotrichum fragrans em manipueira. Energia na Agricultura, v. 14, n. 2, p. 7-14, 1999.

[9] DANIELS, L.; HANSON, R.; PHYLLIPS, J.A. Chemical analysis. In: GERHARDT, P.; MURRAY, RGE.; WOOD, W.A.; KRIEG, N.R (Ed.) Methods for General and Molecular Bacteriology. American Society for Microbilogy. Washington DC., p. 518-519, 1994.

[10] DEMYTTENAERE, J. C. R.; VANOVERSCHELDE, J.; DE KIMPE, N. Biotransformation of (R)-(+)- and (S)-(-)citronellol by Aspergillus sp. and Penicillium sp. and the use of solid phase microextraction for screening. J. Chromatogr. A, v. 1027, n. 1-2, p.137-146, 2004.

[11] DUETZ, W. A.; BOUWMEESTER, H.; VAN BEILEN J. B.; WITHOLT, B. Biotransformation of limonene by bacteria, fungi, yeasts, and plants. Appl. Microbiol. Biotechnol., v. 61, n. 4, p. 269-27, 2003.

[12] GRAVEL, D.; BORDELEAU, J. Photochemical Rearrangement of 2-Phenylthio-1,3-cyclohexanediols to Deoxysugars. Application to a Stereospecific Synthesis of (+)-cis-Rose Oxide. Tetrahed. Let., v. 39, n. 44, p. 8035-8038, 1998.

[13] GRIFFIN, S.; WYLLIE, S. G.; MARKHAM, J. Determination of octanol-water partition coefficient for terpenoids using reversed-phase high-performance liquid chromatography. J. Chromatogr. A., v. 864, n. 2, p. 221-228, 1999.

[14] KAMINSKA, J.; MARKOWICZ, L.; STOLOWSKA, J.; GÒRA, J. Biotransformation of citronellol by means 
of horseradish peroxidase. Enz. Microbiol. Technol., v. 11, n. 7, p. 436-438, 1989.

[15] KUMAR, K. V.; UMAR, M.; SINGH, A. P.; BRIJ, L.; RAJ, N. H.; VIRENDRA, S. Patent number: WO03080777, Publication date: 2003-10-02, Application number: WO2002IB01205 20020325.

[16] KUIATE, J. R.; BESSIÈRE, J. M.; ZOLLO, P. H. A. Composition of the essential oils from three Laggera Spp from Cameroon. Flav. Fragr. J., v. 17, n. 2, p.105-108, 2002.

[17] LEONEL, M.; CEREDA, M. P. Citric acid production by Aspergillus niger from "Manipueira", a manioc liquid residue. Scient. Agric., v. 52, n. 2, p. 299-304, 1995.

[18] NELSON, N, A photometric adaptation of the Somogy method for determination of glucose. Biochem. v. 153, n. 1, p. 375-380, 1945.

[19] NITSCHKE. M.; PASTORE, G. M. Cassava Flour Wastewater as a Substrate for Biosurfactant Production. Appl. Biochem. Biotechnol., v. 106, p. 295-302, 2003.

[20] ONKEN, J.; BERGER, R. G. Biotransformation of citronellol by the basidiomycete Cystoderma carcharias in an aerated-membrane bioreactor. Appl. Microbiol. Biotechnol., v. 51, n. 2, p.158-163, 1999.

[21] ONKEN, J.; BERGER, R. G. Effects of R-( $\alpha$ )-limonene on submerged cultures of the terpene transforming basidiomycete Pleurotus sapidus. J. Biotechnol. v. 69, n. 2-3, p. 163-168, 1999.

[22] SCHRADER, J.; BERGER, R. G. Biotechnological Production of Terpenoid Flavor and fragrance compounds.
In: REHM, H. J., REED, G. ( $2^{\text {nd }}$ Ed), Biotechnology. Weinheim: Wiley-VHC, 2001. Chap. 3, p. 384-388.

[23] SERRA, S.; FUGANTI, C.; BRENNA, E. Biocatalytic preparation of natural flavours and fragrances, Trends Biotechnol., v. 23, n. 4, p. 193-198, 2005.

[24] SIKKEMA, J.; DE BONT, J. A. M.; POOLMANN. B. Interactions of Cyclic Hydrocarbons with Biological Membranes. J Biol. Chem., v. 269, n. 11, p. 8022-8026, 1994.

[25] SOMOGY, M. A. A new reagent for determination of sugar. J. Biol. Chem., v. 160, n. 1, p. 61-68, 1944.

[26] TAN, Q. \& DAY, D. F. Bioconversion of limonene to $\alpha$ terpineol by immobilized Penicillium digitatum. Appl. Microbiol. Biotechnol., v. 49, n. 1, p. 96-101, 1998.

[27] TANEJA, S. C.; SETHI, V. K.; ANDOTRA, S. S.; KOUL, S.; QAZI, G. N. Rose oxides: a facile Chemo and Chemo-enzymatic Approach. Synth. Communicat., v. 35, n.17, p. 2297-2303, 2005.

[28] VAN DYK, M. S.; VAN RENSBURG, E.; MOLELEKI, N. Hydroxylation of (+)-limonene, (+)- $\alpha$-pinene and (-) $\beta$ pinene by a Hormonema sp., Biotechnol. Let., v. 20, n. 4, p. 431-436, 1998.

[29] YOUNGCHIM, S.; HAY, R. J.; HAMILTON, A. J. Melanization of Penicillium marneffei in vitro and in vivo. Microbiol. v. 151, n. 1, p. 291-299, 2005.

\section{6 - ACKNOWLEDGEMENTS}

This project was funded by CNPq, Brazil (Process number 141601/2004-3). 